\title{
Latitudinal species diversity and density of cryptic crustacean (Brachyura and Anomura) in micro-habitat Autonomous Reef Monitoring Structures across Kepulauan Seribu, Indonesia
}

\author{
GESTEN HAZERI ${ }^{1}$, DWI LISTYO RAHAYU ${ }^{2}$, BEGINER SUBHAN ${ }^{1}$, ANDRIANUS SEMBIRING ${ }^{3}$, \\ AJI WAHYU ANGGORO ${ }^{3}$, AHMAD TAUFIK GHOZALI ${ }^{1}$, HAWIS H. MADDUPPA, ${ }^{1, \bullet}$ \\ ${ }^{1}$ Department of Marine Science and Technology, Faculty of Fisheries and Marine Science, Institut Pertanian Bogor. Jl. Raya Dramaga, IPB Campus \\ Dramaga, Bogor 16680, West Java, Indonesia. ”email: hawis@apps.ipb.ac.id. \\ ${ }^{2}$ Marine Bio-industry Implementation Unit, Research Center for Oceanography, Indonesian Institute of Sciences. Teluk Kodek, Pemenang, Lombok \\ Utara 83352, West Nusa Tenggara, Indonesia \\ ${ }^{3}$ Yayasan Biodiversitas Indonesia. Jl. Tukad Balian No. 121, Denpasar 80226, Bali, Indonesia
}

Manuscript received: 11 April 2019. Revision accepted: 29 April 2019.

\begin{abstract}
Hazeri G, Rahayu DL, Subhan B, Sembiring A, Anggoro AW, Ghozali AT, Madduppa HH. 2019. Latitudinal species diversity and density of cryptic crustacean (Brachyura and Anomura) in micro-habitat Autonomous Reef Monitoring Structures across Kepulauan Seribu, Indonesia. Biodiversitas 20: 1466-1474. Kepulauan Seribu is located in the north of Jakarta and has historically been affected by anthropogenic activities. Based on its anthropogenic pressure, the archipelago is divided latitudinally into three main parts; the southern part, is a collection of islands located closest to Jakarta Bay and characterized by poor water quality, large sediment and pollutant inputs from nearby rivers, the central and north part that possesses a better water quality. Brachyura and Anomura are dominant crustacean groups in the ocean, which inhabited areas from littoral zone to the deep sea. However, its diversity and abundance are relatively understudied especially in the area where anthropogenic pressure is severe like Kepulauan Seribu. The ARMS (Autonomous Reef Monitoring Structure) is a standardized monitoring method systematically designed for observing indications of organism's biodiversity in units of time. This research was conducted by employing ARMS as a standardize monitoring procedure to catalog and provide census of Crustaceans (Brachyuran and Anomuran) distributed across the archipelago. All crustacean inhabiting each unit of ARMS were collected and identified. Species diversity was then evaluated to see whether gradient in anthropogenic pressure has a direct impact on species composition and abundance. A total of 24 ARMS units were deployed from 2013 to 2016 , located in three zones: south (9), central (9) and north (6) of Kepulauan Seribu. This study identified 17 species from 8 different families of Brachyura and 11 Anomura species from 4 different families from all sites. However, low available identification references for Indonesian crustacean made some specimen were identified only up to family level. The highest species diversity of Brachyura was recorded from family Xanthidae, followed by Portunidae and Pilumnidae, while in Anomura was in Porcellanidae, followed by Paguridae, Galatheidae, and Diogenidae. The high species diversity and density of brachyurans and anomurans were recorded in the central zone. This research infers that the species diversity of Crustaceans (Brachyura dan Anomura) seems dependent on the environmental quality, but most likely all crustacean species depend on the availability of habitat structure.
\end{abstract}

Keywords: Biosystematics, urban reefs, taxonomy, habitat complexity

\section{INTRODUCTION}

Brachyura and Anomura are two dominant organism groups in the seawater around the world. These groups of crabs inhabit the coastal areas to the deep sea. Indonesia is an archipelagic country with $70 \%$ of its territorial is water that possesses a high species diversity of marine biotas (Suharsono 2014). According to Anggraeni et al. (2015), 34 species and 11 families of crabs (Brachyura) in the Pari Island, Kepulauan Seribu. Those crabs are distributed in various habitats and different substrates based on species and adaptation to the environment. Furthermore, changes in water ecosystem quality and substrates affect the abundance and diversity of crabs and other biotas (Purnami et al. 2010; Worm et al. 2012: Anggraeni et al. 2015).

The ARMS (Autonomous Reef Monitoring Structure) is a method that is designed systematically to be able to observe biodiversity indication in a certain time unit. This method has purposes to afford an analysis standard method of taxonomy and molecular for assessing the biodiversity of invertebrate, to escalate an ability for measuring and discovering the diversity of cryptic organisms globally all the time, to heighten the ecosystem by management based, to intensify the capability in monitoring and predicting ecological impacts of global climate change especially ocean acidification and ocean warming (Zimmerman and Martin 2004). The ARMS actually has been developed as a standard method to emulate a complex structure of coral reef habitat and attract invertebrate colonies and algae (Plaisance et al. 2011; Ransome et al. 2017; David et al. 2019). The research utilized the ARMS in Indonesia are relatively new. The first ARMS installment in Indonesia, are established in 2010 at Sanger Talaud (North Sulawesi), collaborative research between LIPI (Indonesian Institute of Science) and NOAA. In 2011, ARMS are submerged in Raja Ampat and Bali for observing the biodiversity of 
those locations The coral reefs of Kepulauan Seribu located in the north of Jakarta has been affected by anthropogenic activities and probably influence the coral reef communities (Zaneveld and Verstappen 1952; Madduppa et al. 2013; Fahlevy et al. 2019). The Kepulauan Seribu is divided into three main parts such as the south part that is the nearest part to the mainland and many inputs from rivers coming in which has poor water quality, central part that possesses a relatively good water quality, and north part which has a better water quality (Sachoemar 2008). A significant different species density along the environmental gradient in the Kepulauan Seribu is also observed in reef fishes (Madduppa et al. 2013). However, none studies have conducted on group of Brachyura and Anomura. The classification of the gradient is intended to seek the differences of Crustacean (Brachyura and Anomura) found in each unit of ARMS. However, research regards to the species diversity of Crustacea in the Kepulauan Seribu, Jakarta, is still rare.

Therefore, this research aimed to analyze the species diversity of Crustacea (Brachyura and Anomura) along the environmental gradient of Kepulauan Seribu, Jakarta.

\section{MATERIALS AND METHODS}

\section{Study sites}

The study was conducted along the environmental gradient of Kepulauan Seribu, Jakarta, Indonesia (Figure 1). A total of 24 2-year-old ARMS from September 2016 to February 2017 were recovered from study sites (Table 1). The Kepulauan Seribu was classified into three environmental gradients zone based on their distance from Jakarta: South Zone (Bidadari, Lancang Besar, and Pari), Central Zone (Tidung, Karang Beras, and Pramuka), and North Zone (Kotok and Sepa).

\section{Data collection}

Data collection of Crustaceans (Brachyura and Anomura) was taken in each unit of ARMS according to the ARMS' handling standards which described as follows. The ARMS unit in the sea bottom was taken up by covering the unit used a filter bucket $(100 \mu \mathrm{m})$ to avoid the organisms in the unit escaping. The unit then was put in a storage bucket containing seawater and aerated for preventing the organisms' mortality. The ARMS unit was discharged in the storage bucket by disconnecting each plate layer utilized wrench that had been prepared. Each layer of the plate was documented. After that, those plates had been removed and documented; using clean seawater in a container to eliminate sessile and non-sessile organisms that were still attached at ARMS plates then cleaned those plates. Further, the organisms in the container were filtered. All gathered organisms were sorted and identified by using an identification book for each sample until higher taxa. Those identified organisms were then documented and then extracted (preserved). All samples were stored in the collecting bottles containing ethanol 96\% (Plaisance et al. 2011).

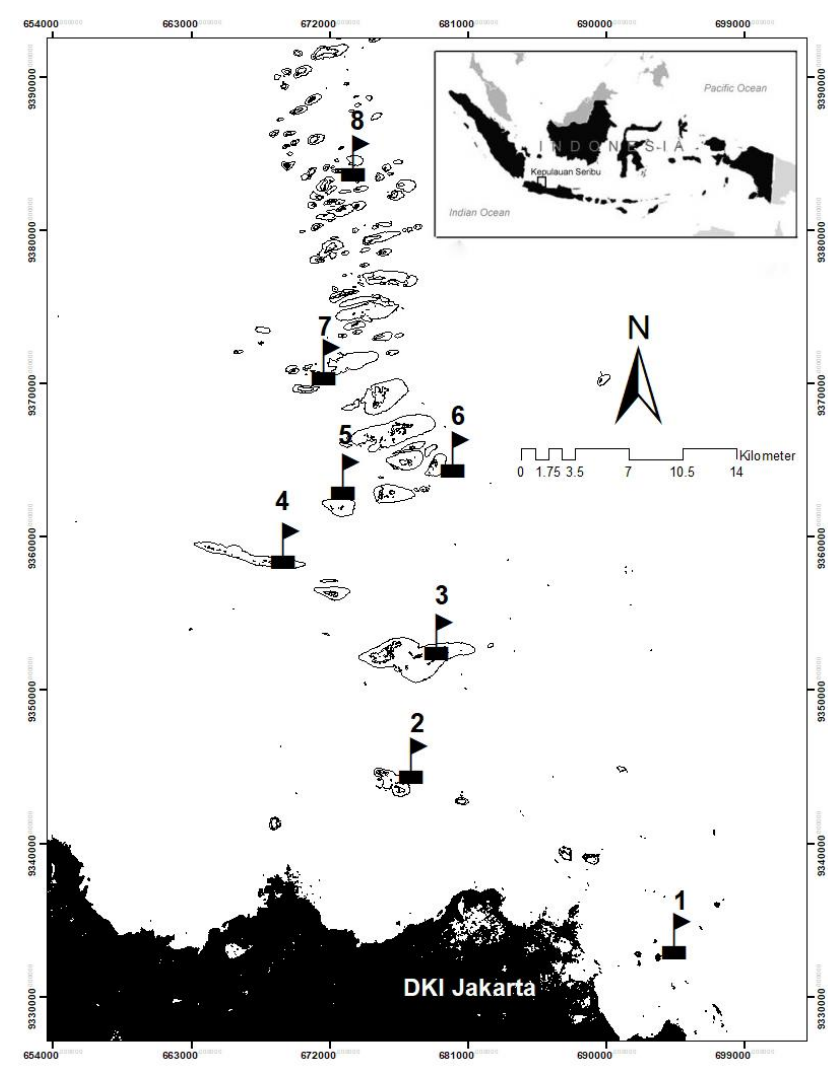

Figure 1. The study sites within Kepulauan Seribu, Jakarta Bay, Indonesia: Refer number from Table 1 for name of each island

Table 1. Name of the island, zone, number of ARMS and their distance from Jakarta, Indonesia coordinates of the study

\begin{tabular}{|c|c|c|c|c|c|}
\hline \multirow{2}{*}{ Zone } & \multirow{2}{*}{ Island } & \multirow{2}{*}{ Number of ARMS } & \multirow{2}{*}{$\begin{array}{c}\text { Distance from } \\
\text { Jakarta }(\mathbf{k m})\end{array}$} & \multicolumn{2}{|c|}{ Coordinate } \\
\hline & & & & South latitude & East longitude \\
\hline South & Bidadari & 3 & 22.06 & $-6,034382$ & 106.749045 \\
\hline South & Lancang Besar & 3 & 42.3 & -5.927527 & 106.579388 \\
\hline South & Pari & 3 & 46.11 & -5.869805 & 106.613277 \\
\hline Central & Tidung & 3 & 57.4 & -5.800510 & 106.53400 \\
\hline Central & Karang Beras & 3 & 57.9 & -5.765944 & 106.564638 \\
\hline Central & Pramuka & 3 & 57.5 & -5.75012 & 106.60100 \\
\hline North & Kotok & 3 & 65.64 & -5.68600 & 106.53600 \\
\hline North & Sepa & 3 & 75.86 & -5.572972 & 106.580305 \\
\hline
\end{tabular}




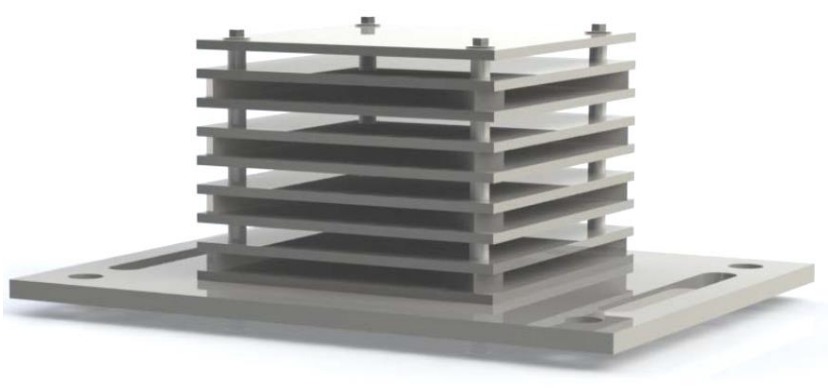

Figure 2. The ARMS (Autonomous Reef Monitoring Structure) Unit (Base Plate was a PVC with the size of $450 \mathrm{~mm} \times 350 \mathrm{~mm} \times$ $12.7 \mathrm{~mm}$ and layer plate was a PVC with the size of $225 \mathrm{~mm} \mathrm{x}$ $225 \mathrm{~mm} \times 6.3 \mathrm{~mm})$

\section{Species identification}

The Crustacean (Brachyura and Anomura) was identified according to their forms and morphological characteristics up to genus and species level. Some gathered crab species were difficult to be identified either genus or species level due to the specimens' condition was ruinous, and these specimens were identified up to family level. Brachyura identification was following to Moosa (1980), Jones and Morgan (1994), Widyastuti (2003), Chan et al. (2009), Rahayu and Ng (2010), and Anggraeni et al. (2015). Identification of Anomura was following to Asakura and Tachikawa (2003), McLaughlin et al. (2007), McLaughlin et al. (2010), and Osawa and McLaughli (2010).

\section{Data analysis}

The Shannon-Wiener diversity index (H') and Evenness index (E) were calculated based on the natural logarithm (ln) (Krebs 1989; Shannon dan Weaver 1949). The T-test: single factor was used to examine difference between two same variables with a confidence level of $95 \%(0.05)$ using Minitab Excel 2013. The dendrogram based on similarity of Bray-Curtis (MDS) was taken to visualize the difference in the crustacean communities (Brachyura and Anomura) from different gradients zone (Kruskal 1964; Shepard 1962; Madduppa et al. 2013).

\section{RESULTS AND DISCUSSION}

\section{Species diversity and density}

A total of 17 species from 8 different families Brachyura was discovered in all sites (Table 2). The highest species diversity was recorded from family Xanthidae (6 species), followed by Portunidae (2) and Pilumnidae (2). Each family of Hymenosomatidae, Majidae, Palicidae, and Leucosiidae consisted of only one species. The highest density and diverse were observed in central zone. A total of 109 individuals of brachyuran were recorded at study sites (Figure 3 ). The highest density was observed in Central Zone (80 individuals), which was coming from Karang Beras Island, Tidung Island, and Pramuka Island. In the North (Kotok Island and Sepa Island) were recorded 21 individuals. The lowest density was observed in the South (Bidadari Island, Lancang Besar Island, and Pari Island).

A total of 11 Anomura species from 4 different families were recorded from study sites (Tabel 2). The total species of Porcellanidae, Paguridae, Galatheidae, and Diogenidae, was 5 species, 4 species, 1 species, and 1 species, respectively. The highest species richness was observed in the Central (15 species). Two other zones (North and South) were recorded 8 and 6 species, respectively. A total of 101 individuals of Brachyura was recorded in all zone of study sites (Figure 3). The highest density was discovered in the Central gradient (Karang Beras Island, Tidung Island, and Pramuka Island) with 59 individuals. The South gradient (Bidadari Island and Lancang Besar Island and Pari Island) tends to possess less (31 individuals). Whilst the North gradient (Kotok Island and Sepa Island) is the least density gradient with only 11 individuals found.

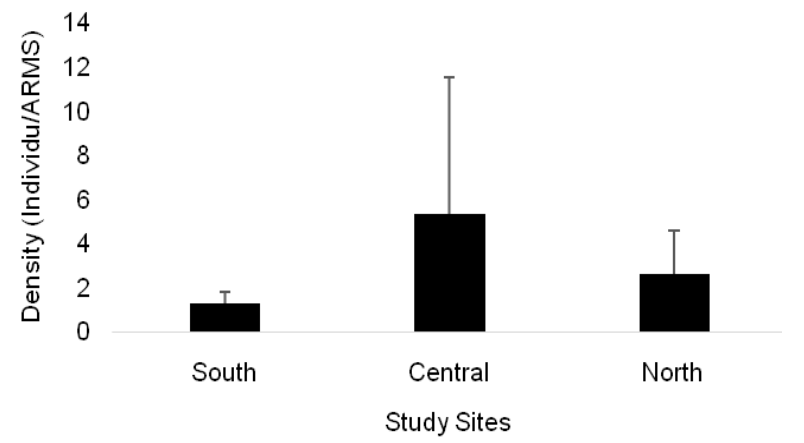

A

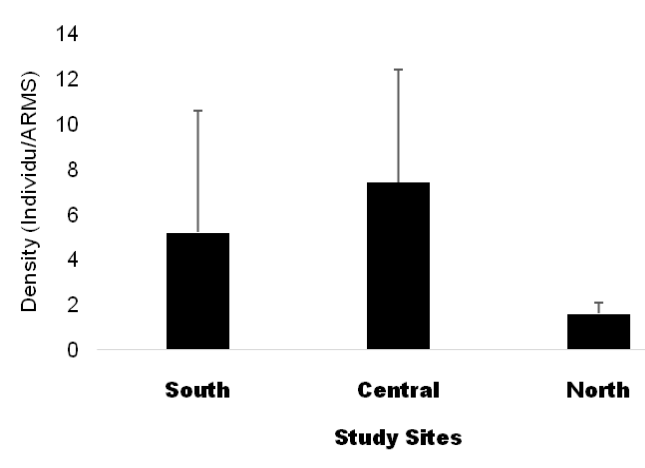

B

Figure 3. The density (individual/ARMS) of total brachyuran (A) and anomuran (B) from an ARMS unit at each latitudinal environmental gradient study sites (south, central and north) across Kepulauan Seribu, Indonesia 
Table 2. Family and species of discovered Brachyura and Anomura in each environmental gradient latitudinal zone (South, Central, and North) across Kepulauan Seribu, Indonesia

\begin{tabular}{|c|c|c|c|c|}
\hline \multirow{2}{*}{ Family } & \multirow{2}{*}{ Species } & \multicolumn{3}{|c|}{ Zone } \\
\hline & & South & Central & North \\
\hline \multicolumn{5}{|l|}{ Brachyura } \\
\hline Hymenosomatidae & Unidentified hymenosomatid crab & 1 & 1 & - \\
\hline Majidae & Majidae sp. & 1 & - & - \\
\hline \multirow[t]{2}{*}{ Pilumnidae } & Pilumnus sp. & 1 & 17 & 7 \\
\hline & Viaderiana $\mathrm{sp}$. & - & 1 & - \\
\hline \multirow[t]{3}{*}{ Portunidae } & Thalamitapicta & 1 & 6 & 1 \\
\hline & Thalamitadanae & 2 & 15 & 2 \\
\hline & Thalamita sp. & - & 1 & 1 \\
\hline \multirow{2}{*}{ Trapeziidae } & Trapezia $\mathrm{sp}$ & - & 1 & - \\
\hline & Trapezia cymodoce & - & 2 & - \\
\hline \multirow{6}{*}{ Xanthidae } & Actaeodes sp. & 2 & 16 & 4 \\
\hline & Pilodius sp. & - & 12 & 2 \\
\hline & Marcomedaeus sp. & - & 2 & - \\
\hline & Liptodius & - & 2 & - \\
\hline & Xanthias sp. & - & 2 & 2 \\
\hline & Zosimusaeneus & - & 1 & - \\
\hline Palicidae & Unidentified palicid crab & - & 1 & - \\
\hline Leucosiidae & Unidentified leucosid crab & - & - & 2 \\
\hline \multicolumn{5}{|l|}{ Anomura } \\
\hline \multirow[t]{4}{*}{ Paguridae } & Pagurixus sp. & 12 & 7 & 2 \\
\hline & Unidentified pagurid 1 & 12 & - & - \\
\hline & Unidentified pagurid 2 & - & 6 & 1 \\
\hline & Pagurus sp. & - & - & 2 \\
\hline Diogenidae & Diogenes sp. & - & - & 1 \\
\hline Galatheidae & Galathea sp. & 4 & 11 & - \\
\hline \multirow[t]{5}{*}{ Porcellanidae } & Polyonyx sp. & 1 & 2 & - \\
\hline & Petrolisthes sp. & 1 & 16 & 2 \\
\hline & Pasidia sp. & 1 & 4 & 1 \\
\hline & Pachycheles sp. & - & 11 & 2 \\
\hline & Polyonyxboucheti & - & 2 & - \\
\hline
\end{tabular}

\section{Community structures}

The Shannon-Wiener diversity index (H') and Evenness index (E) of Brachyura and Anomura are shown in Table 3. The highest diversity $\left(\mathrm{H}^{\prime}\right)$ of Brachyura was observed in the Central (2.14). All zones were categorized as low diversity for Brachyura $\left(\mathrm{H}^{\prime}<3.32\right)$. While, the Evenness index of Brachyura showed the highest in the south (0.96). Furthermore, the highest diversity $\left(\mathrm{H}^{\prime}\right)$ of Anomura was observed in the north (1.89), but all zones were categorized as low diversity $\left(\mathrm{H}^{\prime}<3.32\right)$. The Evenness index $(\mathrm{E})$ of Anomura was observed high in the north (0.97).

The species diversity of Brachyuran in Kepulauan Seribu was not significantly different. For Anomura, the significant difference was only observed between Central and North. This is due to differences in the average value of individual density in the number of species found in the central and north gradients, where the number of Anomura species on the central and north gradients is almost the same, while the number of individuals is far apart.

Table 3. The Shannon-Wiener diversity index (H') and Evenness index (E) of Crustacean (Brachyura and Anomura) along the gradients of Kepulauan Seribu, Jakarta Bay, Indonesia

\begin{tabular}{lcccc}
\hline Species & Index & South & Central & North \\
\hline Brachyura & Diversity (H') & 1.73 & 2.14 & 1.86 \\
& Evenness (E) & 0.96 & 0.79 & 0.89 \\
Anomura & Diversity (H') & 1.33 & 1.87 & 1.89 \\
& Evenness (E) & 0.74 & 0.90 & 0.97 \\
\hline
\end{tabular}

Table 4. Statistical analysis T-test: single factor of species diversity of crustacea (Brachyura and Anomura)

\begin{tabular}{lccc}
\hline Species & South and Central & South and North & Central and North \\
\hline Brachyura & $0.40(\mathrm{sig}>0.05)$ & $0.13(\mathrm{sig}>0.05)$ & $0.27(\mathrm{sig}>0.05)$ \\
Anomura & $0.54(\mathrm{sig}>0.05)$ & $0.56(\mathrm{sig}>0.05)$ & $0.01(\mathrm{sig}<0.05)$ \\
\hline
\end{tabular}




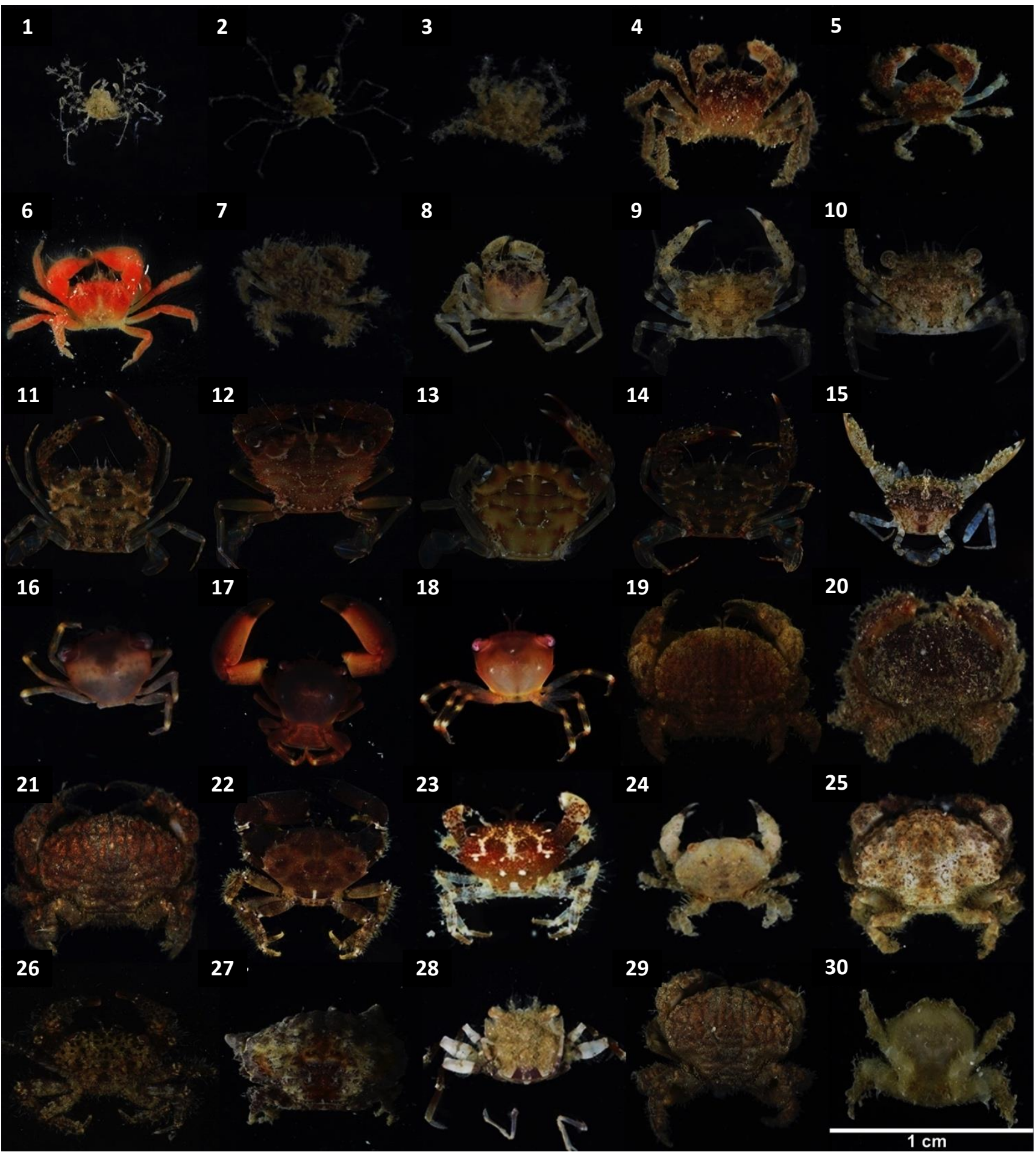

Figure 4. Brachyuran species discovered in the environment gradients of Kepulauan Seribu, namely: $(1,2)$ Unidentified hymenosomatid crab, (3) Majidae sp., (4,5,6,7) Pilumnus sp., (8) Viaderiana sp., $(9,10)$ Thalamitapicta, $(11,12,13,14)$ Thalamitadanae, (15) Thalamita sp., (16) Trapezia sp., (17,18) Trapezia cymodoce, (19,20,21) Actaeodes sp., (22,23) Pilodius sp., (24) Marcomedaeus sp., (25) Liptodius (26,27) Xanthiassp., (28) Unidentified palicid crab, (29) Zosimus aeneus and (30) Unidentified leucosid crab (bar = $1 \mathrm{~cm})$ 


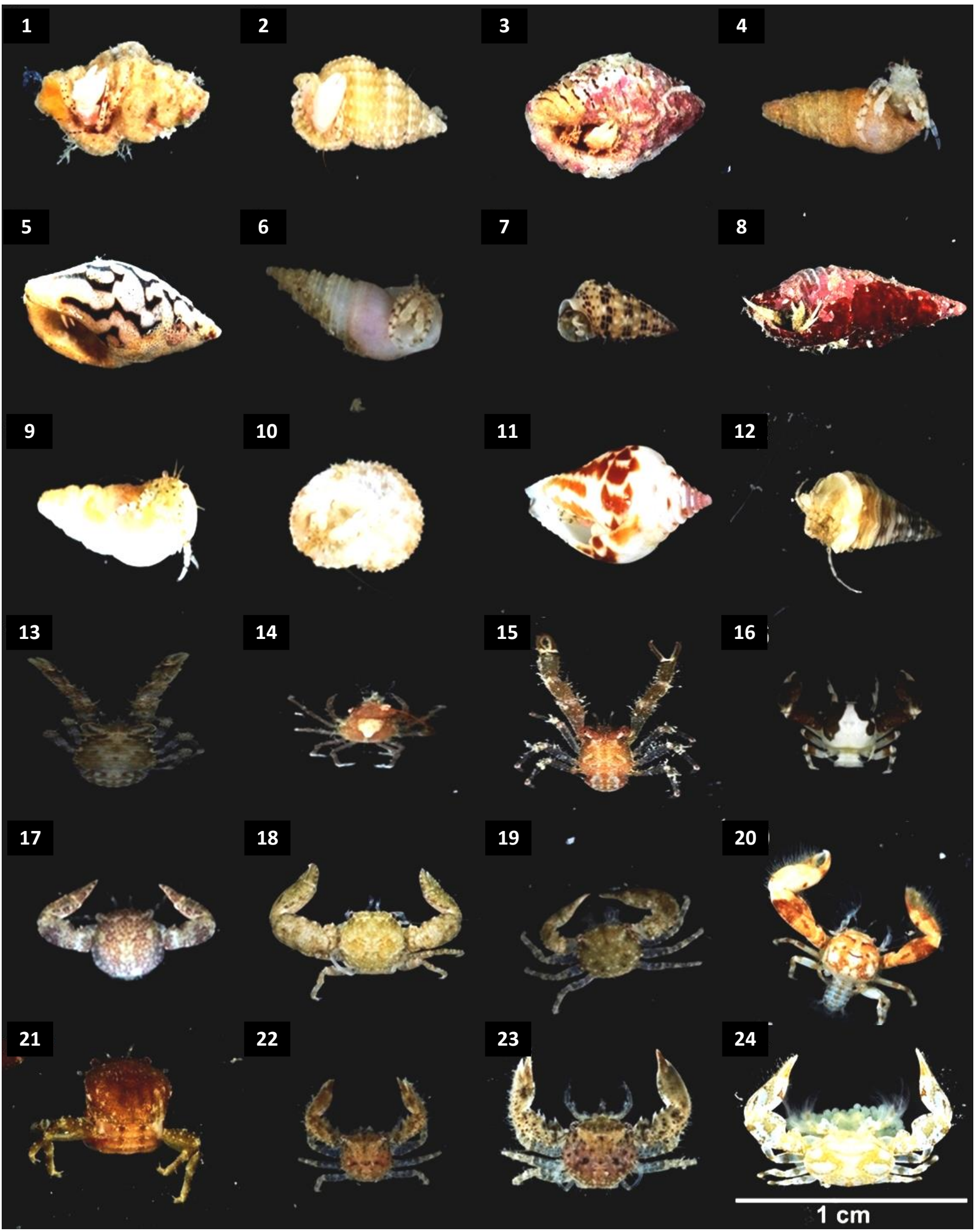

Figure 5. The discovered Anomura species in the environment gradient of Kepulauan Seribu, namely: (1, 2, 3, 4) Pagurixus sp., (5, 6, 7) Unidentified pagurid 1, (8, 9) Unidentified pagurid 2, (10,11) Pagurus sp., (12) Diogenes sp., (13, 14, 15) Galathea sp., (16, 17) Polyonyx sp., (18, 19, 20) Petrolisthes sp., (21) Pasidia sp., (22, 23) Pachycheles sp., and (24) Polyonyx boucheti $(\mathrm{bar}=1 \mathrm{~cm})$ 


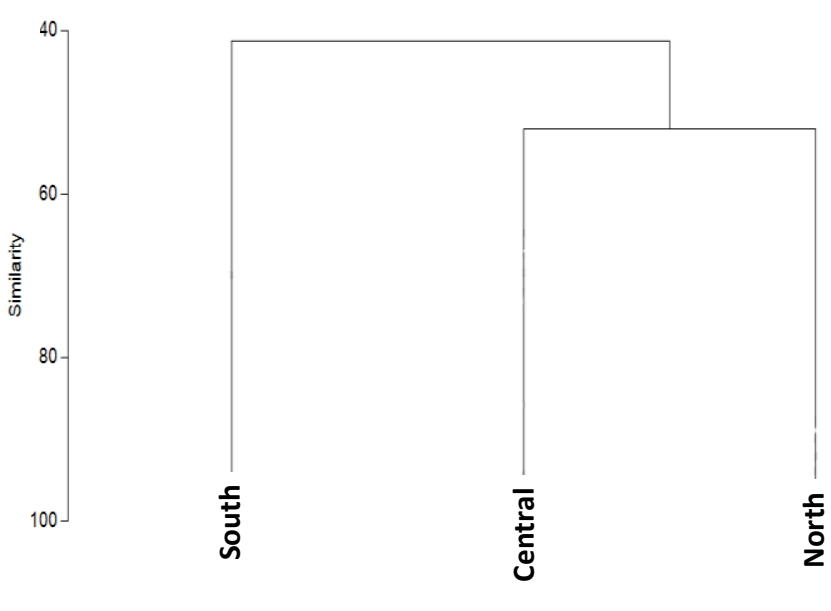

A

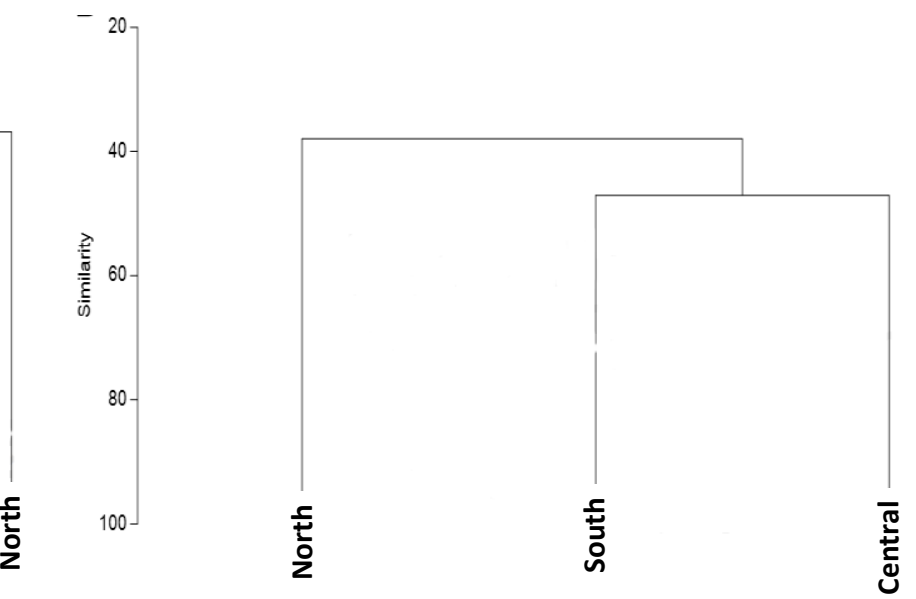

B

Figure 6. The dendrogram based on the Bray-Curtis species similarity of Brachyura (A) and Anomura (B) along the gradient zone of Kepulauan Seribu, Jakarta, Indonesia

The dendrogram analysis of density and diversity of the Crustacean (Brachyura and Anomura) used a similarity index of Bray-Curtis categorized three gradients (south, middle, and north) of Kepulauan Seribu based on the density and diversity of the crustacean (Brachyura and Anomura), as shown in Figure 6. The results showed that Brachyura was categorized into two zone groups (1= south, $2=$ central and north), while Anomura was divided into two groups $(1=$ north, $2=$ central and south $)$.

\section{Discussion}

This study showed 17 species from 8 different families of Brachyura and 11 Anomura species from 4 different families in all sites. The highest species diversity of Brachyura was recorded from family Xanthidae (6 species), followed by Portunidae (2) and Pilumnidae (2). The Xanthidae is a family of crabs that are well known as gravel crabs and most of them are found in the hard substrates (Aswandy 2008). The Xanthidae consists of eight subfamilies (Sakai 1976). Some species of family Xanthidae are brightly colored and categorized containing a toxin or toxic (Jones and Morgan 1994). The following families are Portunidae and Pilumnidae. Three species of family Portunidae which had been discovered in this research come from the same genus is Thalamita. The family of Portunidae commonly has characteristics such as a pair of swimming leg and 4-5 anterior edge spines (Anggraeni et al. 2015; Pratiwi and Widyastuti 2013). The Pilumnidea is a superfamily of crabs, which consists of three families such as Pilumnidae, Galenidae, and Tanaocheleidae. Two species were discovered in this research coming from family Piumnidae namely Pilumnus sp.and Viaderianasp. These kinds of crab species are in general inhabited intertidal areas with dead coral substrate until $75 \mathrm{~m}$ depth for several certain species (Spivak and Rodriguez 2002). Other least family such Majidae was also observed which possesses common characteristics such as oval carapace shape, the length of the carapace is bigger than its width, and shaping a point at the carapace's edge. Some species of this family have very long legs like spider crab (Majasquinado). Another typical feature of this family is coated by feathers from some algae, which some species used them for camouflage (Ahyong et al. 2005). The family Trapeziidae is one of crab family, which is commonly well known as coral crab. Almost all species of this family are found in a symbiotic condition with several types of Cnidarian. The varied species of Trapeziidae crabs are discovered in Indo-Pacific areas. They can be identified until species level based on the differences in their color patterns (Castro et al. 2004).

In Anomura, the highest species diversity was observed in Porcellanidae, followed by Paguridae, Galatheidae, and Diogenidae. A total of 101 individuals of Brachyurawas recorded in all zone of study sites. The family Paguridaeis is well known as a family of hermit crabs. Most species have long, spirally curved abdomens. They are different from other common Crustaceans; these hermit crabs possess soft textures of the abdomen. They utilize empty seashell of snail to protect their bodies especially the vulnerable abdomen (Wiliams and McDermott 2004). They can pull back all parts of their bodies into the seashell to protect their bodies in responding to disturbance or treats of predators. The edges of the abdomen of these crabs have adapted in order to be able to grip strongly the columella of the snail's seashells (Chapple 2002). There are four species of Paguridae found in this research namely Pagurixus sp., Pagurus sp., and two other unidentified species in genus level (unidentified pagurid land unidentified pagurid 2). The family of Galatheidaeis a small group crustacean which is rarely seen, however, in certain times some of the species are swarmed in large numbers. They possess similarity with small lobsters (Jones and Morgan 1994). 
This family is very diverse and consists of 675 species in 34 genera (Baba et al. 2008). The current research only found a species of Galatheidae namely Galathea sp. The family Porcellanidae is commonly admitted as porcelain crab that composes of 283 species (Osawa and McLaughlin 2010). The family of Porcellanidae is commonly discovered in bottom sandy substrate with coral rubble. It spreads in the area of "Indo West Pacific" like Indonesia, Japan, Thailand, and Australia (Trivedi and Vachrajani 2013). In this current research, only five species of this family found in the research location namely Polyonyx sp., Petrolisthes sp., Pisidia sp., Pachycheles sp. and Polyonyxboucheti. The family of Dioginedae often called as hermit crabs due to its family members have a left claw bigger than the right one (McLaughlin et al. 2007). This family in principle inhabits in the tropical areas and warm water, most of this family live in the Indo-Pacific waters. From 20 species existing, 8 of them live in Taiwan waters (McLaughlin et al. 2007).

The most density and most diverse of both Brachyura and Anomura were observed in the Central zone (Karang Beras Island, Tidung Island, and Pramuka Island). The south gradient (Bidadari Island and Lancang Besar Island and Pari Island) tends possessing less diversity for both groups. These trends also observed from other fish communities in Kepulauan Seribu (Madduppa et al. 2013). A stress or pressure level received by a certain water environment can be determined by the diversity and homogeneity (Lardicci et al. 1997; Wijaya and Pratiwi 2011). The ranges of homogeneity index (E) of Brachyura and Anomura were ranged 0.79-0.96 and 0.74-0.97, respectively. These values showed that not any species tendency dominate the population in the research locations (Odum and Barrett 2005; Harsono et al. 2016). The diversity indexes ( $\left.\mathrm{H}^{\prime}\right)$ of Brachyura and Anomura showed low level in three zones $\left(\mathrm{H}^{\prime}<3.32\right)$. Whilst, high homogeneity index (E) of Brachyura and Anomura was observed in the south, central and northern zones. The species diversity of Brachyuran in the Seribu Island gradients was not significant between all gradients, but Anomura was significantly observed between Central and North. This is due to differences in the average value of individual density in the number of species found in the central and north gradients, where the number of Anomura species on the central and north gradients is almost the same, while the number of individuals is far apart. Other gradients do not occur in either the Anomura or Brachyura species. The results of this research signify that Brachyura was categorized into two zone groups $(1=$ south, $2=$ central and north), while Anomura was divided into two groups ( $1=$ north, $2=$ central and south). These figures showed to be linked to the environmental factors such sedimentation, pollution, and other human activities in Jakarta Bay and Kepulauan Seribu (Willoughby 1986; Reese et al. 1999; Rachello-Dolmen and Cleary 2007; Madduppa et al. 2013).

In conclusion, this study identified 17 species from 8 different families of Brachyura and 11 Anomura species from 4 different families in all sites. However, low available identification references for Indonesian crustacean made some specimen were identified only up to family level. The high species diversity and density of brachyurans and anomurans were recorded in the central zone. This research infers that the species diversity of Crustaceans (Brachyura dan Anomura) seems dependent on the environmental quality and habitat availability.

\section{ACKNOWLEDGEMENTS}

The study was a part of the USAID's Partnerships for International Research and Education (PIRE) Project. We would like to thank Prof. Paul Barber and Dr. Chris Meyer for assistance during the project. Thanks to the Laboratory of Marine Biodiversity and Biosystematics, Bogor Agricultural University (IPB), Indonesia, University of California Los Angeles, Smithsonian Institute, and Indonesia Biodiversity Research Center in perspective collaboration for conducting and completing this research. We extend our gratitude to Kepulauan Seribu Marine National Park for research permit.

\section{REFERENCES}

Ahyong ST, Chen H, Ng PKL. 2005. Pleistacantha stilipes, a new species of spider crab from the South China Sea (Decapoda: Brachyura: Manidae). Zootaxa 822: 1-10.

Anggraeni P, Elfidasari D, Pratiwi R. 2015. Brachyuran Crab distribution in Tikus Island, Pari Island Group, Seribu Islands. Pros SemNas Mays Biodiv Indon. 1 (2): 213-221. [Indonesian]

Asakura A, Tachikawa H. 2003. Hermit Crabs of the Genus Calacinus Dana, 1851 from Japan and Adjacent waters (Decapoda, Anomura, Diogenidae): C. Hazletti Haig \& McLaughlin, 1984 and C. Haigae Wooster, 1984. Crustaceana 76 (6): 717-739.

Aswandy I. 2008. Crustaceans as Consumers in Seagrass. Oseana 33 (1): $1-9$.

Baba K, Macpherson E, Poore GCB, Ahyong ST, Bermudez A, Cabezas P, Lin C, Nizinski M, Rodrigues C, Schnabel KE. 2008. Catalogue of squat lobsters of the world (Crustacea: Decapoda: Anomura-families Chirostylidae, Galatheidae and Kiwaidae). Zootaxa 1905: 1-220

Castro P, Ng PKL, Ahyong ST. 2004. Phylogeny and Systematics of the Trapeziidae Miers, 1886 (Crustacea: Brachyura), with the description of a new family.Zootaxa 643: 1-70.

Chan TY, Ng PKL, Ahyong ST, Tan SH. 2009. Crustacean Fauna of Taiwan: Brachyuran Crabs, Volume 1-Carcinology in Taiwan and Dromiacea, Raninoida, Cyclodorippoida. Huayu Nature Book Trade Co.Ltd. Taiwan

Chapple WD. 2002. Mechanoreceptors innervating soft cuticle in the abdomen of the hermit crab, Paguruspollicarus. J Comp Physiol A. 188: 753-766

David R, Uyarra MC, Carvalho S, Anlauf H, Borja A, Cahill AE, Carugati L, Roberto Danovaro R, De Jode A, Feral J, Guillemain D, Lo Martire M, Laure Thierry De Ville D'Avray LTV, John K. Pearman JK, Chenuil A. 2019. Lessons from photo analyses of Autonomous Reef Monitoring Structures as tools to detect (bio-)geographical, spatial, and environmental effects. Mar Biol Poll 141: 420-429

Fahlevy K, Prabowo B, Mubarok MWI, Fahrezi FY, Abdurrahman MI, Prasetia MF, Wicaksono RZ, Aprizan M, Subhan B, Madduppa H. 2019. Comparing hard coral cover between Panggang and Kelapa Island Administrative Village, Seribu Islands National Park, Indonesia. IOP Conf Ser Earth Environ Sci. DOI: 10.1088/1755$1315 / 241 / 1 / 012036$

Harsono GD, Jailani, Hamdani. 2016. Study of Fish Communities on Seagrass Bed Ecosystems in the Waters of Sapa Segajah Bontag, East Kalimantan. Trop Fish Sci J. 22 (1): 074-081.

Jones DS, Morgan GJ. 1994. A Field Guide to Crustaceans of Australian Waters. First published in 1994 by Reed a part of William Heinemann Australia, Chatswood, NSW 2067. 
Krebs CJ. 1989. Ecological Methodology Second Edition. University of British. Columbia. Species Diversity Measures. Chapter 13 version 5 23: $532-593$.

Kruskal JB. 1964. Multidimensional scaling by optimizing goodness of fit to a nonmetric hypothesis. Psychometrika 29: 1-27.

Lardicci C, Rossi F, Castelli A. 1997. Analysis of macrozoobenthic community structure after severe dystrophic crises in a Mediterranean Coastal Lagoon. Mar Poll Bull 34 (7): 536-547.

Madduppa HH, Subhan B, Suparyani E, Siregar AM, Arafat D, Tarigan SA, Alimuddin, Khairudi D, Rahmawati F, Bramandito A. 2013. Dynamics of fish diversity across an environmental gradient in the Seribu Islands reefs off Jakarta. Biodiversitas 14 (1): 17-24

McLaughlin PA, Boyko CB, Crandall KA, Komai T, Lemaitre R, Osawa M, Rahayu DL. 2010. Annotated Checklist of Anomuran Decapod Crustaceans of the World (Exclusive of the Kiwaoidea and Families Chirostylidae and Galatheidae of the Galatheoidea)-Preamble and Scope. Raffles Bull Zool. 23: 1-4

McLaughlin PA, Rahayu DL, Komai T, Chan TY. 2007. A Catalog of the Hermit Crabs (Paguroidea) Of Taiwan. National Taiwan Ocean University Keelung, Taiwan.

Moosa M.K. 1980. Some Notes About Crabs from the Bay of Jakarta and Seribu Islands.Marine Biological Resources. Summary of Some Research Results II. National Oceanographic Institution, LIPI Jakarta. Indonesia.

Odum EP, Barrett GW. 2005. Fundamentals of Ecology. 5th ed. Thomson Brooks/Cole, Belmont, CA.

Osawa M, McLaughlin PA. 2010. Annotated Checklist Of Anomura Decapod Crustaceans Of The World (Exclusive Of The Kiwaoidea and Families Chirostylidae and Galatheidae of The Galatheoidea) Part II-Porcellanidae. Raffles Bull Zool Suppl 23: 109-129.

Plaisance L, Brainard R, Caley MJ, Knowlton N. 2011. Using DNA barcoding and standardized sampling to compare geographic and habitat differentiation of crustaceans: A Hawaiian Islands Example. Diversity. 4: 581-591.

Pratiwi R, Widyastuti E. 2013. Portunidae tribe crabs (Decapoda: Brachyura) from Indonesian waters. Oceanographic Research Center, Indonesian Institute of Sciences. Jakarta, Indonesia.

Purnami AT, Sunarto, Setyono P. 2010. Study of benthos community based on diversity and similarity index in Cengklik Dam Boyolali. Ekosains. 2 (2): 50-56. [Indonesian]

Rachello-Dolmen PG, Cleary DFR. 2007. Relating coral traits to environmental conditions in the Jakarta Bay/PulauSeribu reef complex, Indonesia. Estuar Coast Shelf Sci 73: 816-826.

Rahayu DL, Ng PKL. 2010. Notonyx Guinotae, A new Species of Goneplacid Crab (Brachyura, Goneplaxidae) from Lombok Island, Indonesia. Studies on Brachyura: 269-278.
Ransome B, Geller JB, Timmers M, Leray M, Mahardini A, Sembiring A, Collins AG, Meyer CP. 2017. The importance of standardization for biodiversity comparisons: A case study using autonomous reef monitoring structures (ARMS) and metabarcoding to measure cryptic diversity on Moorea coral reefs, French Polynesia. PLoS ONE 12 (4): e0175066. DOI: 10.1371/journal.pone.0175066

Reese JG, Setiapermana D, Sharp VA, Weeks JM, Williams TM. 1999.Evaluation of the impacts of land-based contaminants on the benthic faunas of Jakarta Bay, Indonesia. Oceanologica Acta 22: 627640

Sachoemar. 2008. Characteristics of the aquatic environment in Seribu Islands. Indonesian Water J 4 (2): 109-114.

Sakai T.1976. Crabs of Japan and the Adjacent Seas. Kodansha Ltd, Tokyo

Shannon CE, Weaver W. 1949. The Mathematical Theory of Communication.University of Illinois Press, Urbana.

Shepard R. 1962. The analysis of proximities: Multidimensional scaling with an unknown distance function. II. Psychometrika 27: 219-246.

Spivak DE, Rodriguez A. 2002. Pilumnus reticulatus Stimpson, 1860 (Decapoda: Brachyura: Pilumnidae) a reappraisal of larval characters from laboratory reared material. J Sci Mar 66 (1): 5-19

Suharsono. 2014. Indonesia Marine Biodiversity. Species of Richness, Distribution, Abundance, Benefit and Economic Value. Oceanographic Research Center-Indonesian Institute of Sciences. Jakarta. Indonesia.

Trivedi JN, Vachhrajani KD. 2013. First record of two Porcellanid crabs from Gujarat state, India (Crustacea: Decapoda: Porcellanidae). J Mar Biol 55 (1): 55-58

Widyastuti E. 2003. Poisonous Crabs, Xanthidae Tribes. Oseana 28 (2): 11-19.

Wijaya NI, Pratiwi R. 2011. Spatial Distribution of Crustaceans in waters Matasiri Islands, South Borneo. Mar Sci 16 (3): 125-134.

Wiliams JD, McDermott JJ. 2004. Hermit crab biocoenoses: a worldwide review of the diversity and natural history of hermit crab associates. $\mathbf{J}$ Exp Mar Biol Ecol 305 (1): 1-128.

Willoughby NG. 1986. Man-made litter on the shores of the Thousand Island Archipelago, Java. Mar Poll Bull 17: 224-228

Worm B, Bodreau SA. 2012. Ecological role of large benthic Decapods in marine ecosystems: A review. Mar Ecol Prog Ser 469: 195-213

Zaneveld JS, Verstappen HTH. 1952. A recent investigation about the geomorphology and the flora of some coral islands in the Bay of Djakarta. J Sci Res 3: 58-68.

Zimmerman TL, Martin JW. 2004. Artificial Reef Matrix Structures (ARMS): an inexpensive and effective method for collecting coral reef-associated invertebrates. Gulf Caribbean Res 16: 59-64. 